\title{
Rahvakalendrist, astroarheoloogiast ja pidustuse tähtsusest ühiskonnas
}

Tõnu Ülemaante

\begin{abstract}
Teesid
Kirjutis tutvustab üht seni suhteliselt vähe levinud lähenemisviisi eesti rahvakalendri käsitlemisel. Paistab, et kalendritähtpäevad moodustavad teatud kindla süsteemi ning nende konkreetsed kuupäevad tulenevad eelkõige astronoomiast ja matemaatikast, mitte niivõrd põllumajanduslikest töödest, nagu seni on tavapäraselt arvatud. Lähemalt vaadeldakse nelja, väidetavalt kristluse-eelsest ajast pärinevat tähtpäeva taliharja-, künni-, karuse- ja kolletamispäeva. Need päevad sobivad üsna täpselt aastat kuueteistkümneks osaks jaotavasse kalendrisüsteemi, mida Euroopas on seostatud muistsete, astronoomiliselt orienteeritud megaliitehitistega. Ilmselt oli selline kalendrisüsteem tuntud ka Eestis ja seega võiks siin leiduda ka vastavaid rajatisi.
\end{abstract}

Märksõnad: astroarheoloogia, kalendrisüsteemid, megaliitehitised, muinasastronoomia, pühad ja pidustused, rahvakalendri tähtpäevad

Selle kirjutise ajendiks sai 2002. aasta viimastel päevadel aset leidnud seltskonnavestlus, mille käigus kerkis taas kord esile mind juba pikka aega huvitanud küsimus, kas ühiskonnas on vaja religioosseid pidustusi. Tuleb kohe märkida, et sõnal religioosne on siinkohal tavapärasest laiem tähendus ning selle all pean ma pigem silmas midagi niisugust nagu ehtne, sügav, mõtestatud, tõelise sisuga jne. Nimelt on mulle (nagu ehk ka paljudele teistele) juba tükk aega teinud muret kõikvõimalike tähtpäevade, pühade ja pidustuste üha kiirenev devalveerumine.

Üheks selliseks näiteks on minu arvates lausa maniakaalse ulatuse võtnud sünnipäevade tähistamine, mis mõneski suuremas töökollektiivis kipub kujunema permanentseks sünnipäevapeoks. Iseenesest on see muidugi kena, mis aga (kui üle päeva kutsutakse klaasikest veini jooma) võib ühel hetkel tüütuks muutuda. Eriti, kui pärast tuleb tööd jätkata. Teiseks näiteks oleksid kõikvõimalikud kontserdid ja muud õlle-ranna-grilli-party'd, mis vähemalt suvekuudel samuti üheks lõputuks peoks kisuvad.

Püüan siinkohal selle nähtuse põhjustest ja tagamaadest aru saada. Ehk on pühad ja pidustused inimühiskonnale kuidagi loomuomased ja koguni hädavajalikud? On ju ajaloolased ja antropo-

http://haldjas.folklore.ee/tagused/nr28/kalender.pdf 


\section{Tõnu Ülemaante}

loogid nende olemasolu täheldanud kõikidel aegadel ja kõikide rahvaste juures alates loodusrahvastest ja lõpetades muistsete kõrgkultuuridega.

Siinkohal aga tulebki pähe üks oluline erinevus: nimelt on ajaloost ja etnograafiast tuntud pühadel ja pidustustel olnud olemas see ehtne, sügav, mõtestatud, tõeline sisu, mis paistab tänapäeval (vähemalt Eestis) üha ähmasemaks muutuvat ja kohati täiesti kaduvat. Devalveerunud pidustustel ei ole aga enam algset kvaliteeti ja seda püütakse kompenseerida kvantiteedi lisamisega. Nii korraldatakse "üritusi" järjest rohkem, kuid paraku pakuvad need osavõtjaile (sageli küll pigem pelgalt pealtvaatajatele) üha vähem tõelist rahuldust. See omakorda sunnib järjest uusi pidusid korraldama ja nõnda ongi nõiaring kujunemas.

Omaette probleemiks on veel mitmesuguste võõrpäritolu tähtpäevade Eestisse sissetoomine, nagu näiteks halloween, valentinipäev, Püha Patricku päev, kui mõned esimesena meelde tulevad üles lugeda. Kuid eks neidki või vaadelda just sellessamas kvantiteedi lisamise kontekstis.

Kuid millised peaksid siis olema tõelised pühad ja pidustused? Ühest küljest on meil võimalus pöörduda rahvakalendri ja rahvapärimuse uurimise poole, kuid mingil põhjusel on mulle isiklikult selle küsimuse puhul pakkunud huvi hoopis üks teine, asjaga esmapilgul hoopis vähem seotud teadusharu - astronoomia. Nimelt tundub mulle, et tõelisel pühal või pidustusel peaks olema mingi palju fundamentaalsem alus kui seda on folkloor. Ning nõnda jõuamegi eesti (ja loomulikult mitte ainult eesti) rahvakalendri kahe kõige olulisema tähtpäeva -jõulude ja jaanipäevani. Nende pühade puhul on ülalmainitud tõeline sisu (ehk siis astronoomiline alus) olemas ja julgen oletada, et talvist ja suvist pööripäeva on peetud aastaringi olulisteks tähtpäevadeks juba sellest ajast alates, kui inimene siin maailmas on olemas olnud.

Kahjuks ei ole isegi nende pühade käsi tänapäeva Eestis kõige paremini käinud. Ehkki hea õnne korral võib isegi Tallinna lähedal mõnusale traditsioonilisele jaanitulele sattuda, kipub seegi sageli õlle-ranna-grillipeoks muganduma.

Midagi hoopis hullemat on juhtunud aga jõulude - talvise pööripäevaga. Siinjuures ei pea ma silmas mitte ainult viimaste aastate kasvavat kommertsialiseerumist. Osalt ilmselt nõukogude pärandi tõttu, aga osalt ka juba palju varasemast ajast pärinevatel põhjustel on suur osa inimesi (massimeedia kaasa arvatud) pähe võtnud, 


\section{Tõnu Ülemaante}

et jõulud on mingisugused "kodused pühad". Kuidas on võimalik nii loomuvastase väite peale tulla? Minu teada ei ole ajaloolased ega antropoloogid oluliste kalendritähtpäevadega seonduvalt sellist asja nagu kodused pühad kunagi ega kusagil täheldanud. Pühad ja pidustused on alati tähendanud seda, et kogu suguharu, hõim või küla tuleb traditsioonilise tähtpäeva puhul n-ö keskväljakule kokku. Milliseid konkreetseid rituaale või kombetalitusi sel puhul läbi viiakse või millised tavad või pidusöömaajad sellega kaasas käivad, on hoopis eraldi küsimus. Lisaks on ajalooliselt olulisemaid traditsioonilisi tähtpäevi peetud sageli mitu päeva järjest, mis omakorda annab kogu asjale hoopis teise mõõtme kui näiteks ühelainsal õhtul korraldatav söömaaeg.

Mis puutub aga talvisesse pööripäeva, siis vähemalt meie kliimavöötmes on see olulisimaid ja samas ka psühholoogiliselt ehk kõige positiivsema mainega tähtpäev üldse. Ehkki ilmad veel niipea soojemaks minema ei hakka, on päevade lühemaks muutumine selleks korraks lõppenud ja kui see pole rõõmus sündmus, siis tekib küsimus, millal on siis üldse põhjust rõõmu tunda.

Hoolimata sellest väikesest kriitikast julgen kinnitada, et talvine ja suvine pööripäev on just need tähtpäevad, millel on kahtlemata astronoomiline ja seega looduse poolt kaasa antud põhjendus, ning kui üritame leida, millised pühad võiksid olla tõelised, siis ülalnimetatud tähtpäevad on seda. Ning kas ei ole tegelikult just sellise sisu olemasolu põhjuseks, miks need pühad on ühiskonnas läbi aegade olnud olulisimal kohal - välisest vormist ja selle muutumisest sõltumatult.

Pöördugem nüüd aga tagasi käesoleva kirjutise algusesse, kus oli juttu ühest seltskonnavestlusest. Nimelt ärgitas just see vestlus mind teemaga lähemalt tegelema. Kõigepealt meenus omal ajal loetud ja mäletamist mööda huvitavana tundunud raamat - Gerald S. Hawkinsi Stonehenge pole ainus (originaalpealkiri Beyond Stonehenge). Mul ei tulnud selgi korral pettuda ja pärast mõningast lehitsemist sattusin lõigule, mis käsitletava teemaga haakus:

Loengujärgsete küsimuste esitajad mainisid palju kordi beltane'i tulesid. Aasta astronoomilistel tähtpäevadel sü̈̈dati Šotimaal, Iirimaal ja Briti saarte teistes osades suured lôkked -just nagu Päikese käändest sõltuvad interpunktsioonimärgid. See rituaal püsis üheksateistkümnenda sajandi keskpaigani. Kirjalikud tõendid selle kohta on mõnevõrra sega- 


\section{Tõnu Ülemaante}

sed, sest ristiusumisjonärid pü̈̈dsid sellele lõppu teha, lõkete sü̈̈tamist kirikukalendri tähtpäevadele lükata või, kui see ei ónnestunud, uut religiooni märkamatult vanade tavadega ühte sulatada (Hawkins 1980: 194).

Vahemärkusena ütlen, et ilmselt tuleb viimast lauset ka eesti rahvakalendri tähtpäevade uurimisel tähelepanelikult silmas pidada. Kõikvõimalike kristlike tegelaste maskeerimisvõrk paistab kohati olevat väga tihe ja kavalasti üles seatud ning selle taha piilumine nõuab omajagu nutikust.

G. S. Hawkins jätkab:

Lõkked sü̈̈dati üle maa suvise ja talvise päikeseseisaku ning kevadise ja sügisese võrdpäevsuse ajal. Inglismaal Norwichis veeretati igal suvisel pööripäeval künkast alla tuleratas, mis sümboliseeris allakäiguteed alustavat päikeseketast.

Lõkked sü̈̈dati ka neljal päeval, mil Päikese põhja- või lõunapoolne kääne oli 16,3․ See kääne fikseeris kuupäevad-praeguse gregooriuse kalendri järgi ligikaudu 4. veebruari, 6. mai, 8. augusti ja 8. novembri-, mil päikeseseisakutest või võrdpäevsustest oli möödunud üks kaheksandik aastat. Aasta jagunes seega kaheksaks enam-vähem võrdseks osaks. See jaotus on väga lähedane megaliitehitiste päikesesuundadel rajanevale jaotusele, mida täheldas Thom ja enne teda Lockyer. Et need ehitised on püstitatud enne druiidide aega, siis võivad beltane'i tuled pärineda ajaloo hämarusest.

Talvise pööripäeva beltane'i tulesid asendavad nü̈̈d (elektrilised) jõulukü̈̈nlad. Juutide hanukaküünlad on võib-olla samasuguse kalendrilise päritoluga. Veebruari tuled sulatas endasse suur kirikupüha kü̈̈nlapäev, mil jällegi põletati küünlaid. Kuuenda mai tähistamine on segunenud esimese mai tähistamisega. Novembripidustused on üle võtnud kiriklik kõigi pühakute päev. Ameerika Ühendriikides asendavad tolle päeva eelõhtul druiide lapsed, kes ande kogudes ühe ukse tagant teise taha käivad. See näib olevat "lokaalne traditsioon" - väljaspool Ameerikat minu teada selletaolist kõigi pühakute päeva eelõhtu rituaali ei eksisteeri (Hawkins 1980: 194).

Siinkohal tekib ilmselt igal eestlasel kohe tahtmine G. S. Hawkinsile vastu vaielda. Nii oli see ka minu puhul. On ju samasugune "lokaalne traditsioon" olemas ka Eestis - mardipäeva tavana. Lisaks 


\section{Tõnu Ülemaante}

paikneb päikese käändega seonduv, astronoomiliselt fikseeritud hetk -8 . november - mardipäevale (10. november) palju lähemal kui kõigi pühakute päevale (1. november).

Ehkki G. S. Hawkins ei räägi midagi lähemalt 8. augusti kohta, teame, et näiteks eesti rahvakalendris on 10. augustil lauritsapäev. Seega ei jää muud üle kui tõdeda, et samasugused, kindlate astronoomiliste hetkedega seonduvad tähtpäevad on ka eesti rahvakalendris.

Et asi mind mingil põhjusel üha enam ja enam huvitama hakkas, võtsin järgmiseks kätte Heino Eelsalu raamatu Ajastult ajastule. Huvipakkuv lõik ei lasknud end kaua otsida.

Esmasteks pidepunktideks põhjala kalendri aastaveerandite kohta võib pidada neid keskajast pärinevaid teateid, mis paigutavad muinasnorra kalendri aastaveerandite alguspäevad järgmistele kuupäevadele: 12. jaanuar, 14. aprill, 14. juuli ja 14. oktoober. Soomes võib leida vihjeid põhjala kalendri kohta juba XVI sajandist pärinevais allikais, kusjuures aastaveerandid seostuvad järgmiste kuupäevadega: 13. või 14. jaanuar, 14. aprill, 13. juuli ja 14. oktoober. Midagi kõneleb nendest kuupäevadest ka meie rahvakalender. Kahtlemata autentne rahvakalendri tähtpäev on künnipäev - 14. aprill. On tõenäoline, et ka karusepäeva - 13. juuli-ja kolletamispäeva-14. oktoober - nimetuse all jäädvustatud tähtpäevad on muinaskalendri jäänukid. Pärast 12. jaanuari aga algab meie rahvakalendris taliharjaga seotud rahvapärimustik (Eelsalu 1985: 23).

Nõnda siis oli mul teada kaksteist erinevat tähtpäeva ja tekkis soov proovida, kas ei anna neid mingisse kindlasse süsteemi sobitada. Juba G. S. Hawkinsi põhjal oli selge, et talvine ja suvine pööripäev ning kevadine ja sügisene võrdpäevsus jaotavad aasta neljaks enamvähem võrdseks osaks. 4 . veebruar, 6 . mai, 8 . august ja 8 . november jaotavad need veerandid omakorda pooleks, mis tähendab, et kokkuvõttes jaguneb aastaring kaheksaks osaks. Samasugust loogikat jätkates sooritasin ma veel ühe jagamise ja tulemuseks oli kuueteistkümneks $(4 \times 4)$ osaks jagatud aasta. Ja mis kõige huvitavam - need neli tähtpäeva, mille puhul $H$. Eelsalu oli väitnud, et need võivad olla pärit muinaskalendrist, paigutusid peaaegu täpselt sellesse skeemi. Taliharjapäev on üks kuueteistkümnendik aastat pärast talvist pööripäeva, künnipäev pärast kevadist võrd- 


\section{Tõnu Ülemaante}

päevsust, karusepäev pärast suvist pööripäeva ja kolletamispäev pärast sügisest võrdpäevsust.

Et asjast selgemat pilti saada, võtsin paberi ja pliiatsi ning nõnda sündiski lisatud skeem (joonis 1 ).

Märkigem, et arvutuslikud kuupäevad on saadud lihtsalt kalendris päevi kokku lugedes ja seetõttu võib skeemis esineda väikesi ebatäpsusi, kuid üldjoontes peaks asi siiski paigas olema. Et pööripäevad teatavasti aastati pisut liiguvad, muutuvad ka ülejäänud kuupäevad, kuid seda mitte rohkem kui 1-2 päeva.

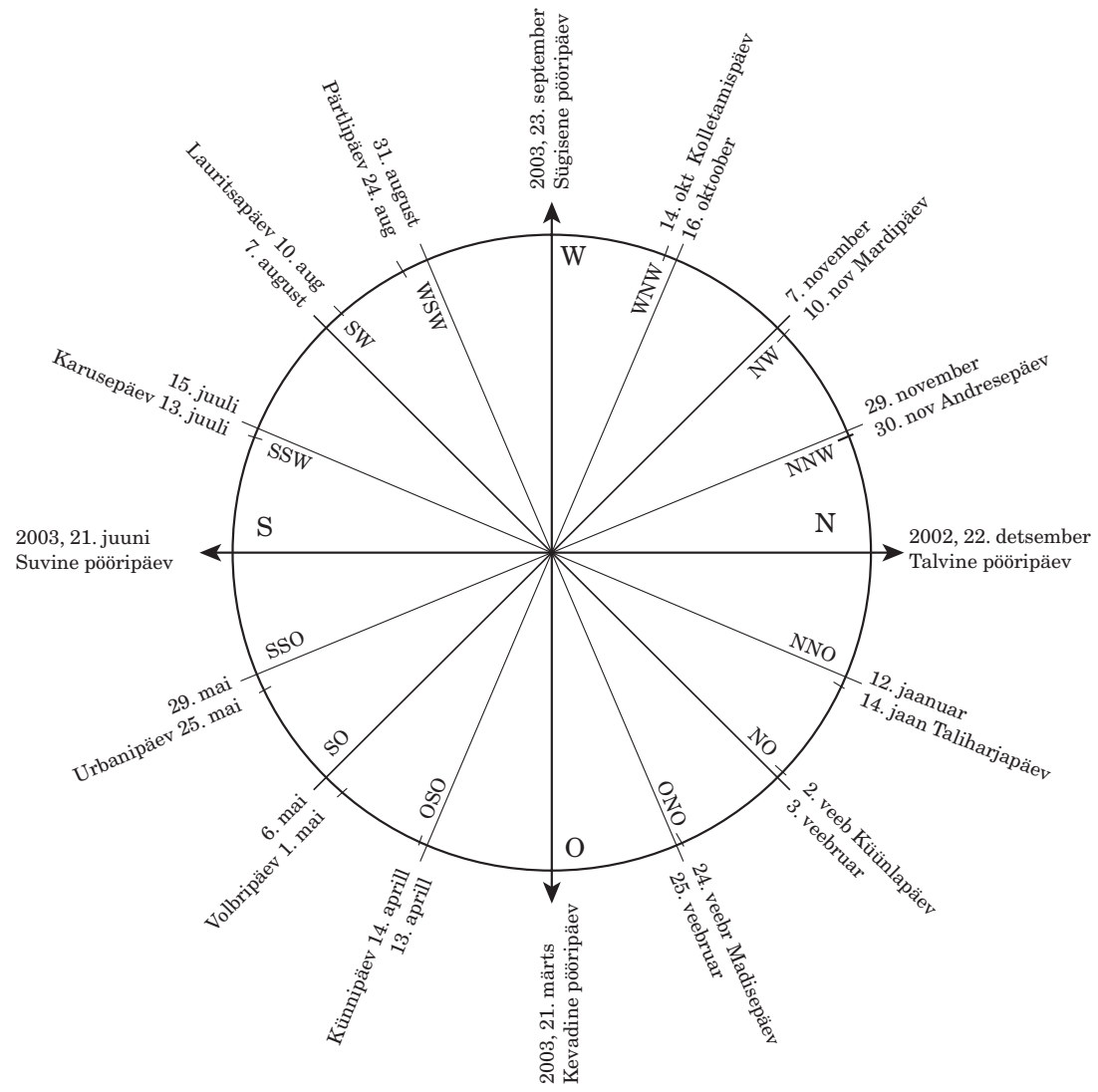

Joonis 1. Aastaringi jagunemine kuueteistkümneks osaks ning sellesse süsteemi sobivad rahvakalendri tähtpäevad. 


\section{Tõnu Ülemaante}

Et skeemi neli positsiooni olid veel tühjad, otsisin ka nendesse kohtadesse kõige lähemal asuvad rahvakalendri tähtpäevad: madisepäev (24. veebruar), urbanipäev (25. mai), pärtlipäev (24. august) ja andresepäev (30. november). Pean tunnistama, et viimatinimetatud konstruktsioon on pisut vägivaldne, pealegi asuvad urbanipäev ja pärtlipäev arvestuslikest tähtpäevadest suhteliselt kaugel. Kui aga võtta aluseks G. S. Hawkinsi mõttekäik, et ristiusu misjonärid üritasid muistseid pühasid kiriklikele tähtpäevadele nihutada, ei peaks selline lähenemisviis olema vastuvõetamatu.

Neli tähtpäeva - taliharjapäev, künnipäev, karusepäev ja kolletamispäev - paistavad ka mitmete teiste uurijate arvates olevat millegi poolest olulised. Näiteks on ka rahvakalendri uurija Mall Hiiemäe pidanud just neid pärinevaks ristiusustamiseelsest ajast:

Kolletamispäev (kolletamise või kolletuspäev) [14. X] on üks neljast tähtpäevast, mida on arvatud kuuluvat ristiusueelsesse, aastat neljaks võrdseks osaks jaotavasse kalendrisüsteemi. Neist on künnipäev (14. IV) ja mareta- ehk karusepäev (13. VII) oma koha tõttu majanduskalendris mõnevõrra rohkem tuntud, ent korjusepäeva (14. I) ja kolletamispäeva tähendus on rahva mälestustest taandunud (Hiiemäe 1991: 212).

Siinkohal olgu igaks juhuks kohe ära toodud ka see täpsustus, mis peaks selgitama korjusepäeva ja taliharjapäevaga seonduvat segadust.

Taliharjapäev (14. I). See päev poolitab talve, soomlased ja karjalased väitsid, et karu pöörab siis teise külje ning hakkab teist käppa imema. Vahepealsed Eesti kalendrid tekitasid pisukese segaduse, kinnitades taliharjapäeva märtsis olevat. 14. jaanuari väideti hoopis korjusepäevaks. Eksitus pärineb enam kui 200 aasta tagant A. W. Hupelilt, segaduse lahendas Gustav Ränk 1975. aastal (Sihvart 2000: 14).

Seda küsimust on käsitlenud ka Lauri Vahtre:

Klimaatilisel alusel kahe peamise aastaaja - soojema ja külmema-eristamist peab M. Nilsson üldse iseloomulikuks kõigile väljaspool troopikavööndit elavatele rahvastele. Ta toob eraldi esile Põhja-Euroopas levinud jaotusviisi, mille kohaselt poolaastate piirid on 14. aprill ja 14. oktoober, millega aasta jaotub juba mitte enam illusoorselt, vaid tegelikult kaheks 


\section{Tõnu Ülemaante}

võrdseks osaks. Seda süsteemi on põhjalikumalt käsitlenud K. Vilkuna. Soomlastel kannavad need kuupäevad "suvipäivä" ja "talvipäivä" nimetust; nende vahele jäävad perioodid on omakorda poolitatud 13. juuli ("keskikesä") ja 14. jaanuari ("talvinapa") abil, nii et tekib neli võrdse pikkusega perioodi. Vilkuna arvab, et samasugune jaotus kehtis eestlastelgi. Kõigile nimetatud kuupäevadele langevad tõepoolest mingid tähtpäevad meie rahvapärimuses: 14. aprill-künnipäev, 13. juuli - mareta- ehk karusepäev, 14. oktoober - kolletamispäev ja 14. jaanuar-talihari. [---]

Tekib küsimus, miks loendamise aluseks on saadud just need ja mitte mõned muud kuupäevad. K. Vilkuna arvates on siin tegemist kõige külmema ja kõige soojema aja "harja" märkimisega 14. jaanuaril ja 13. juulil. Võrdluseks esitab ta Soome aastase keskmise soojuskõvera, mille kõrg-ja madalpunktid vastavad just kõnealustele kuupäevadele (Vahtre 2000: 38).

Viimati osundatud lõigu puhul tekib mõningaid lisamõtteid. See, et 14. jaanuar ja 13. juuli tähistavad aasta tõenäoliselt kõige külmemat ja kõige soojemat aega, on üsna selge. Esineb ju nii Soomes, Eestis kui ilmselt ka mujal Põhja-Euroopas mere läheduse tõttu teatav klimaatiline inerts - see tähendab, et kõige külmem ja kõige soojem ilm ei ole mitte talvisel ja suvisel pööripäeval, vaid pisut hiljem. Sama lugu on ka kevadel ja sügisel, kui klimaatiliselt ei ole kevade ja sügise haripunktid mitte võrdpäevsuse kohal, vaid mõnevõrra hiljem. Aga - ja see on minu arvates väga oluline asi - see ei põhjenda nende tähtpäevade peaaegu täpset asetumist aastat kuueteistkümneks $(4 \times 4)$ jagavasse süsteemi. Kas ei ole nende kuupäevade taga siiski midagi muud?

Siin on sobiv esitada esimene hüpotees: omal ajal Eesti territooriumil kasutusel olnud rahvakalendri alus ei olnud põllumajanduslik, nagu seni on põhiliselt arvatud, vaid astronoomiline ja selle matemaatiliseks koodiks on neljaks (ja sellest loogiliselt tulenev neli korda neljaks) osaks jaotatud (aasta)ring.

Kasutan teadlikult väljendit "Eesti territooriumil", sest nimetatud süsteem võib osutuda nii vanaks ja samas ka nii üleüldiseks, et selle ainult eestlastele omistamine pole kuidagi põhjendatud. Teadaolevalt kinnitavad sellise süsteemi omaaegset olemasolu nii Briti saartel kui ka mitmel pool mujal Lääne-Euroo- 
pas asuvad megaliitehitised ja ei ole välistatud, et midagi niisugust tunti ka Eestis. Seepärast ei ole ma päriselt nõus paari L. Vahtre väitega.

Ehk tundsid eestlased tõepoolest sellist ajajaotussüsteemi, kuid kuna see jaotab kristliku kalendri aastat [minu rõhutus - T.Ü.], siis mitte enne viimase tundmaõppimist.[---]

Kui nelja perioodi lugemine meil kunagi tuntud oli, siis oli see ilmselt pärit Skandinaaviast [minu rõhutus - T.Ü.] ja võis väga hästi kasutusel olla esiteks ainult piirkonniti, teiseks - mitte mõne muu süsteemi asemel, vaid teiste kõrval (Vahtre 2000: 39).

Kuna võib eeldada, et aasta astronoomiliste tähtpäevade põhjal neljaks $(4 \mathrm{x} 4)$ jaotamine on erakordselt vana, ei ole põhjust seostada seda kristliku kalendriga ja ilmselt ei saa seda pidada ka mingiks suhteliselt hiliseks Skandinaavia laenuks.

Teine küsimus on see, mis ajal on niisugune süsteem oma algsel kujul Eestis kasutusel olnud ning millal ja mis põhjustel see unustati.

Hiljemalt 19. sajandiks oli süsteem unustatud - puuduvad täielikult otsesõnalised teated, mis neli kõnealust tähtpäeva kokku seoks. Käsitletava süsteemi kunagine tuntus jääb vaid hüpoteesiks, mis põhineb neljal kalendritähtpäeval. Olgu lisatud, et eesti rahvakalendri kontekstis on need üsna juhuslikud tähtpäevad: 14. jaanuarist ei teatud möödunud sajandil enam midagi peale pseudofolkloorsete väljamõeldiste; 14 . aprill oli künnipäevana küll tuntud, aga tema funktsioon oli segane - kui pidada suvepoolaasta alguseks, jääb arusaamatuks tema paarimehe, karjalaskepäeva (1. aprill) mõte, sisu ja tähendus; 13. juuli, karusepäev, on neljast kõige tuntum, kuid jääb kaugelt alla jaanipäevale ning kombestik ei peegelda uskumust karusepäevast kui suveharjast; 14. oktoobrist, kolletamispäevast, ei mäleta rahvas muud kui vaid nimetust ja seegi teadmine võib vähemalt Mandri-Eestis olla hiline kirjandusmõjuline folkloor (Vahtre 2000: 39).

Ehk põhjustas ülalkirjeldatud süsteemi (just nimelt aastat kuueteistkümneks osaks jaotava süsteemi, sest sellega seonduvad konkreetsed tähtpäevad paistavad olevat enamalt jaolt säilinud, vähe- 


\section{Tõnu Ülemaante}

malt formaalselt) unustusse vajumise mingi uue, näiteks oluliselt täpsemal päevade loendamisel põhineva kalendri kasutuselevõtt, mille tagajärjel kadus otsene vajadus astronoomiliste vaatluste ja seetõttu ka neile vastava aasta jaotamise järele. (Seda, et uus süsteem iga kord täpsem ja parem ei pruugi olla, näitab kas või juuliuse kalender, mille triiv ulatus 20. sajandi alguseks juba umbes paari nädalani.) Võib-olla põhjustasid seda unustamist muutused kultuuris ja religioosses maailmavaates? Koos kõige muuga võis oma osa mängida ka selline esmapilgul tähtsusetuna tunduv faktor nagu ilm. Teatavasti on kliima Põhja-Euroopas tuhandete aastate jooksul korduvalt muutunud ja nõnda võisid nii astronoomilised vaatlused kui ka nendega seonduvad kultuurinähtused kliima halvenedes unustusse vajuda. On ju üsna selge, et pööripäeva päikesetõusu tervitamise tseremoonia ei kujune madala pilvituse ja tibava vihma korral nii imposantseks ja meeliülendavaks sündmuseks kui kirkal suve- või talvehommikul.

Seega on väga raske öelda isegi seda, millal hääbus Eestis astronoomial põhinev süsteem, sest see ei pruukinud tingimata aset leida just muinasaja lõpul (12. sajandil), vaid võis juhtuda juba tunduvalt varem. On teada, et näiteks Kesk-Ameerikas eksisteerinud märkimisväärsete astronoomiaalaste teadmistega maiade kultuur kadus mingitel seniteadmatutel põhjustel juba hulk aega enne eurooplaste vallutusi. Samuti vajusid mingil ajal ja mingil põhjusel unustusehõlma Stonehenge'i rajanud Briti saarte asukate põhjalikud teadmised.

Ehk on isegi üllatav, et paljud selle süsteemiga seonduvad tähtpäevad on jäänud kuigivõrd eesti rahvakalendrisse püsima. Ühe või teise tähtpäeva säilimine või kadumine on aga üldse omaette teema ja sõltub pigem sellest, kas endisaegsel tähtpäeval on uuenenud oludes ja muutunud maailmavaate või religiooni tingimustes otstarve ja mõte.

Niisiis väidan, et nende nelja tähtpäeva - taliharjapäeva, künnipäeva, karusepäeva ja kolletamispäeva - olemasolu eesti rahvakalendris näitab, et Eestis on eksisteerinud aastat kuueteistkümneks osaks jaotav kalendrisüsteem. Nende tähtpäevade paiknemine konkreetsetel kuupäevadel (vastavalt 14. jaanuar, 14. aprill, 13. juuli ja 14. oktoober) on saanud tuleneda ainult astronoomilis-matemaatilisest konstruktsioonist. Põllumajanduslikel ja klimaatilistel nähtustel või lihtsalt juhuslikkusel põhinevad põhjendused ei kõla pa- 
raku veenvalt, sest nende puhul oleks selline matemaatiline täpsus vähetõenäoline ja mitte kuigi arusaadav.

Nüüd aga mõelgem korraks aastat kuueteistkümneks osaks jaotamisel põhineva kalendrisüsteemi ning Briti saartel ja Lääne-Euroopas asuvate astronoomiliselt orienteeritud megaliitehitiste seostele. H. Eelsalu eelosundatud raamatus on ära toodud järgmine seisukoht:

Nii Thomi kui Hindrichsi mõõtmised on näidanud, et Päikese tõusude ja loojangute sihte viseeriti peamiselt eesmärgiga jagada aasta 16 peaaegu võrdseks osaks (Eelsalu 1985: 29).

Seega võib tõdeda, et nende asjade vahel valitseb üsna otsene seos. Kui nüüd eeldada, et niisugust kalendrisüsteemi tunti ka Eestis, võib ühtlasi püstitada hüpoteesi, et ka Eestis peaks leiduma vastava otstarbega astronoomilisi rajatisi.

G. S. Hawkins on märkinud:

"Astronoomiline" kultuurkiht katab Briti saari ja Lääne-Euroopat. Kaks tuhat aastat e.m.a. tunti taeva vastu harrast, kõikehõlmavat huvi (Hawkins 1980: 171).

Et Euroopas leidub niisuguseid rajatisi üsna hulgaliselt ja neid on ehitatud mitmete aastatuhandete jooksul, siis kas pole põhjust oletada, et midagi sellist võis toimuda ka Eestis. Et selleteemalist huvi leidus inimestel veel üsna hiljutiselgi ajal, kinnitab järgmine viide:

Meilgi tunti varasematel aegadel huvi Päikese tõusu sihtide vastu. Näiteks kirjeldab Simeon Aasa ajalehe "Võitlev Sõna" 1982. a. 13. novembri numbris oma noorpõlvemälestusi järgmiselt: "Igas külas oli mõni suurem puu või kivi, mille juures seistes näitas vanem ja agaram külaelanik, kust tõuseb uuel aastal, kust pööripäeval päike. Orientiiriks oli kaugemal kasvav metsatukk või puu" (Eelsalu 1985: 30).

Kuna Eestist ei ole teada mingeid suurejoonelisi muinasaegseid ehitisi, mis oleksid rajatud kas astronoomia uurimiseks või religioossetel või kultuslikel eesmärkidel, ning kuni viimase ajani ei ole vastavaid jälgi leitud ka arheoloogilistel kaevamistel, on ajaloolased niisuguste rajatiste olemasolu siiani eitanud. 


\section{Tõnu Ülemaante}

Läänemeresoomlased ei rajanud muinasajal suuri kultusehitusi oma jumalate austamiseks, nagu seda tegid kõrgkultuurrahvad. Seepärast ei maksa saarlaste ega ka mandrieestlaste juurest otsida päikesetempleid (Lõugas 1996: 101).

Kõigepealt tuleks aga küsida, mida me õieti kultusehitisteks või -rajatisteks peame. Kas Stonehenge on kultuslikel, teaduslikel või maailmavaatelistel eesmärkidel püstitatud rajatis? Mis otstarbel rajati Iirimaal asuv Newgrange? Sedasama võib küsida Woodhenge’i kohta, millest arheoloogid kaevasid välja kindla süsteemi kohaselt paiknevad postiaugud. Samuti tõstatub küsimus, mida me õieti kultusena tõlgendame. Kas talvise pööripäeva päikesetõusule orienteeritud templis koitu tervitav Egiptuse preester sooritas kultuslikku toimingut või hoopis astronoomilist vaatlust, mille eesmärk oli kontrollida kalendrit ehk täpsemalt seda, kas päevade lugemise teel saadud pööripäev ka tegeliku asjade seisuga kokku langeb? Aga järsku tegi ta hoopis mõlemat korraga? Võib-olla ikkagi ei tehtud tol ajal religiooni ja teaduse vahel nii suurt vahet nagu tänapäeval?

Leidsin Vello Lõugase Kaali meteoriidikraatri uurimist käsitlevast raamatust väikese vihje, kust ülalmainitud astronoomilise või religioosse eesmärgiga rajatisi otsida võiks. Nimelt leidub LääneEestis ja saartel mitmeid nn varajasi ringvall-linnuseid, mis pärinevad oletatavasti meie ajaarvamise algusest. Samas pole neid objekte eriti palju uuritud ja väheste arheoloogiliste kaevamiste käigus pole sealt ka suurt midagi leitud. Arheoloogiaraamatuid sirvides tuleb tõdeda, et nende rajatiste algne otstarve pole ehk siiski nii kindel kui nimi eeldaks.

Kaali ringmü̈̈ri kaevamisel meenutasime Saaremaa ja Lä̈̈ne-Eesti analoogilisi müürijäönuseid. Need omapärased "maalinnad" või miniatuursed linnused on köitnud ammu teadlaste tähelepanu, kuigi nende uurimine on piirdunud enamasti üksnes pealiskaudsete vaatluste või proovikaevamistega. Kõnesolevad linnused paiknevad tasasel maastikul, on ümmarguse või ovaalse põhiplaaniga ja ümbritsetud võrdlemisi madala (varisenud, lammutatud) ringvalliga. Mõni varasem autor on pidanud neid isegi suurte maalinnade mudeliks. Kõigile ringvall-linnustele on ühine valliga piiratud alal kultuurkihi peaaegu täielik puudumine. Osalt seletub see tõsiasjaga, et 
asetsedes keset viljelusmaid, on nad olnud mingil ajal kõik kasutusel põllumaana (Lõugas 1996: 97).

Samas teeb V. Lõugas paari niisuguse linnuse kohta huvipakkuvaid tähelepanekuid.

Massu Linnuste ränk paikneb tasasel paepealsel karjamaal. Linnuseõue läbimõõt ulatub 50-60 meetrini, kamardunud vallide laius on keskmiselt 8 meetrit ja kõrgus 1,2 meetrit. Vallis on kaks avaust - väravakohta. Eriti pakub huvi selle ringvalli kohta säilinud rahvapärimus: otse ringi keskel asunud suur kivija selle all kaev. Nagu sirkliga tõmmatud ringjoon punktiga keskel [minu rõhutus - T. Ü.] (Lõugas 1996: 98).

Seega vihjab rahvapärimus sellele, et ringi keskpunkt on olnud ehk mingil moel markeeritud ja kuna sellist informatsiooni on säilitatud, võib oletada, et see oli mingil põhjusel oluline.

Ovaalse põhiplaaniga, kuid analoogse raudkivimü̈̈riga on Ridala kirikust paar kilomeetrit kagu pool asuv Tubrilinn. 19. sajandi kirjeldusest ilmneb, et Tubrilinna vall on nii madalaks lõhutud alles viimastel aegadel. Ajaloolase P. Jordani kirjelduses mainitakse "linna" ümber võimsaid kivimürakaid [minu rõhutus - T.Ü.]. Nüüd on see mü̈rr paar-kolm jalga madalam. Ilmselt on sama saatus tabanud ka teisi eespool kirjeldatud linnusemüüre (Lõugas 1996: 99).

Tubrilinna kohta õnnestus leida veel teinegi vihje:

Jungi järele olla Hausmann seal kaevates maa seest vanu tammepuust sambaid [minu rõhutus - T.Ü.] leidnud, mida vana pihapuuaia jäänuseiks peab (Laid 1923: 78).

Mõistan, et need paralleelid on ehk otsitud, kuid eks seostu ju ka Lääne-Euroopa ja Briti saarte megaliitehitistega suured kivid ja postiaugud. Igatahes märkis ajaloolane Ott Sandrak ühe vestluse käigus, et ta on enamikku neist ringvall-linnusteks nimetatud rajatisi ka ise korduvalt vaatamas käinud ning et igasuguse loogika järgi on neid raske fortifikatsiooniehitisteks pidada. Lisaks sellele, et ringvalli läbimõõt on kohati kaitseehitise kohta kahtlustäratavalt väike ja vall ise väga madal, pidavat need objektid asuma ka 


\section{Tõnu Ülemaante}

linnuse jaoks mitte just kõige sobivamalt valitud paikades. Ka arheoloog Marika Mägi nõustus seisukohaga, et ehk pole nende rajatiste puhul tegemist mitte linnustega, vaid mingite muude objektidega. M. Mägi tõdes samas, et vähemalt tema teada ei ole neid rajatisi mitte kunagi astroarheoloogia vaatevinklist uuritud.

Siinkohal annan endale aru, et võimalikud tulevased arheoastronoomilised uuringud ei pruugi nende objektide puhul mingit tulemust anda. Näiteks võivad tähistena kasutusel olnud kivid olla paigast nihkunud või põllupidamise käigus hoopis minema veetud. Ka on võimalik, et väravakohad on alles hiljem vallist läbi kaevatud. Ja kuna loogilisem on üldse oletada hoopis postide kasutamist, siis ei ole neist ilmselt midagi säilinud. Jääb veel võimalus avastada postiauke, kuid see nõuaks jälle tohutult mahukaid arheoloogilisi kaevamisi.

Samas tuleb tõdeda, et ehkki astroarheoloogial on omad piirangud, annaks selliste märkide leidmine vähemalt mingisugusegi võimaluse mõista muistsete Eesti asukate maailmavaadet. Ühe või teise rajatise pelgalt kultusobjektiks nimetamine ei anna meile mingit teavet. Ehk nagu on öeldud juba korduvalt tsiteeritud raamatus Stonehenge pole ainus:

Maiade nikerdatud friise ja ornamentidega kaunistatud püramiide peetaks veel praegugi puhtakujulisteks groteskseteks kunstiteosteks, kui nendele poleks pilku heitnud arvude vastu huvi tundvad teadlased.

Nagu ütles Halam L. Movius New Yorgi Primitiivse Kunsti Muuseumis peetud loengul: "On ilmne, et need dokumendid [---], nii maalid kui ka gravüürid ja skulptuurid tuleb dešifreerida. Nende nimetamine "tõenäoliselt tseremoniaalseteks” [---] ei ütle mitte midagi [---]” (Hawkins 1980: 153).

Kui tõstatub küsimus, kuidas võisid välja näha riitused ajal, mil astronoomilisi vaatlusi peeti tähtsaks ja need mängisid inimeste maailmavaates olulist osa, siis on selle kohta olemas näide muistsest Egiptusest:

Me tõusime mööda kitsast järsku käsipuudeta treppi väikesesse lahtise taeva all olevasse kambrisse, nõndanimetatud ülemisse päikeseruumi. Seal seisis täisnurkse seinaava ees neljakandiline alabasteraltar. See katusetempel oli pühendatud RaHorachtele, silmapiirilt tõusvale päikesejumalale. Seinal oli pilt, 
mis kujutas ühele põlvele toetuvat, seinaava poole vaatavat ja tõusvat Päikest žestiga tervitavat vaaraod: ma ülistan valju häälega su ilusat nägu, jumalate käskija, Amon-Ra [---].

Me siirdusime tagasi peakorteri jahedusse ja arutasime seal avastust, mille me olime teinud. Templi suund hakkas arusaadavaks muutuma. See mõtestas muistseid poeeme ja müüte. Cheruephi hauakambris, mis pärineb ligikaudu aastast 1400 e.m.a., on öeldud: "Allmaailma uksed on lahti, oo Sokaris, taevane päike. Oo taassündinu, sa paistad säravana silmapiiril ja annad Egiptusele tagasi tema ilu iga kord, kui taevast läbistavad sinu kiired, iga kord, kui sa kettana taevas uuesti sünnid"(Hawkins 1980: 141).

Niisugune maailmavaade ei ole ka tänapäeval täielikult kadunud. Hoolimata vahepealsetest rasketest aegadest on näiteks preeriaindiaanlastel õnnestunud oma tavad ja uskumused üsna hästi säilitada ja kuuldavasti korraldatakse vastavaid tseremooniaid Ameerikas üha rohkem. M ei tea, kui täpselt järgitakse päikesetantsu (Sun Dance) pidustuste aja määramisel astronoomilisi tähtpäevi, kuid ma olen lugenud kusagilt vihjet, et need pidustused peetakse ajal, mil "päike on kõige tugevam", seega ilmselt suvise pööripäeva pai$\mathrm{ku}$.

Lõpetuseks üks sellise tseremoonia kirjeldus:

Tantsijad ärkavad enne päikesetõusu. Nad ajavad üksteist üles ja teadustaja hüüab: "Ärgake, kõik tantsijad, varsti koidab ja meil on algamas tseremoonia, me tantsime tõusvale päikesele!" Nõnda siis tõusevad nad üles ja seavad end valmis. See on ehk viisteist minutit enne päikesetõusu. Kõik tantsijad, naised kaasa arvatud, kogunevad telgi [ingl $\mathrm{k}$ lodge] keskele [tegemist on vabas õhus oleva ümmarguse tantsuplatsiga, mida ümbritseb telgisõrestikku meenutav konstruktsioon tõlk] ja rivistuvad üles, näod ida poole, telgi sissepääsu suunas. Pealtvaatajad peavad hoidma idapoolse tee vaba, et tantsijad näeksid päikesetõusu. Mitte keegi ei seisa tee peal ees. Me tahame tantsida, et õnnistada tõusvat päikest, selleks päevaks ja alatiseks.

Nü̈̈d alustavad lauljad "Päikesetõusu laulu”. Nad laulavad seda laulu enne, kui päike mäe tagant välja piilub, ja nad laulavad võib-olla viis või kümme minutit, samal ajal kui tantsijad seisavad näoga hommikupäikese poole ja puhuvad oma 


\section{Tõnu Ülemaante}

kotkaluust vilesid. Sel hetkel, kui esimene valgusesähvatus üle mäe paistab, sirutavad tantsijad oma käed päikese poole ja seejärel libistavad nad kätega üle oma keha, et iseendid onnistada. Pärast seda, kui päike tervenisti üle silmapiiri on tõusnud, laul lõpeb. See on väga pühalik hetk. Samal ajal rivistuvad väljas seisvad pealtvaatajad kahele poole sissepääsu, ikka veel tantsijaid vaadates, kuid eeldatakse, et mitte keegi ei lähe risti tantsijate eest läbi. Politseinikud jälgivad, et keegi ei läheks risti üle tantsijatest päikese poole suunduva raja.

Pärast seda, kui päike on tõusnud ja laul lõpeb, kogunevad meestantsijad ümber lõkkeaseme, kus tuli on kogu öö põlenud. Seal on rohkesti kuumi süsi. Istume püha lõkke äärde, hobuserauakujuliselt ümber selle. Me ei ümbritse seda, ei sulge läbikäiku ida suunas. Lauljad peavad vahet, kõik peab olema vaikne, sest nü̈̈d on meil, tantsijatel, omakorda laulda neli laulu kindlas järjekorras. Me laulame esimest laulu neli korda ja siis puhume neli korda oma vilesid. Järgmist laulu lauldakse samamoodi neli korda. Ja siis kolmandat, ja siis neljandat. Kõik need tuleb neli korda läbi laulda ja igale laulule järgneb neli korda vilepuhumist (Fitzgerald 1991: 161).

\section{Kirjandus}

Eelsalu, Heino 1985. Ajastult ajastule: [Muinasastronoomia ja -kalendriloo uudsest käsitlusest]. Tallinn: Valgus.

Fitzgerald, Michael Oren 1991. Yellowtail, Crow Medicine Man and Sun Dance Chief: An Autobiography. Norman: University of Oklahoma Press.

Hawkins, Gerald S. 1980. Stonehenge pole ainus. Seeria "A". Tallinn: Valgus.

Hiiemäe, Mall (koost) 1991. Eesti rahvakalender 5: [rahvakombeid jauskumusi]. Tallinn: Eesti Raamat.

Laid, Eerik 1923. Eesti muinaslinnad. Tartu: Loodus.

Lõugas, Vello 1996. Kaali kraatriväljal Phaethonit otsimas. Tallinn: Eesti Entsüklopeediakirjastus.

Sihvart, Anneli (koost) 2000. Tähtpäevi läbi aastasadade.Targu talita raamatukogu. Tallinn: Maalehe Raamat.

Vahtre, Lauri 2000. Eestlase aeg: Uurimus eesti rahvapärase ajaarvamise ajaloost. 2., täiend tr. Tallinn: Varrak. 